\title{
DEVELOPMENT OF THE INFANTILE MOUSE UTERUS: THE EFFECT OF STILBOESTROL
}

\author{
JOYGE KENT \\ Department of Clinical Endocrinology, \\ Birmingham and Midland Hospital for Women, \\ Sparkhill, Birmingham B11 4HL
}

(Received 14th November 1974)

A recent study (Dullaart, Kent \& Ryle, 1975) showed high serum gonadotrophin levels in infantile mice. Initially, the concentration of LH and FSH rose steadily, the former reaching a peak concentration around 9 days after birth then falling by 13 days to the range found in pubertal serum. The concentration of FSH, however, continued to rise until 13 days. The rise in endogenous gonadotrophin levels between 4 and 9 days coincides with rising activities of gonadotrophinresponsive ovarian NAD and NADP diaphorases (Kent \& Ryle, 1975). Marked $3 \beta$-hydroxysteroid dehydrogenase activity is also present in mouse ovaries at this age (Hadjioloff, Bourneva \& Motta, 1973). Increasing steroid biosynthesis, perhaps of oestrogens, may therefore occur and lead to the suppression of $\mathrm{LH}$ release. To investigate this possibility, uterine development was studied during the infantile period. In addition, very young mice were treated with stilboestrol to see whether the uterine changes seen during normal development could be induced prematurely.

Mice of the CFW outbred strain were reared in foster litters of ten females as in the study of ovarian morphology and serum gonadotrophin levels (Kent, 1972; Dullaart et al., 1975). To investigate normal development, pairs of mice from a single litter were killed on Days 4, 5, 6 and 7 and pairs from a second litter were killed on Days 7, 8, 9, 10 and 11. As each pair was removed, it was replaced with males of the same age to maintain a constant litter size. The uteri were fixed for $3 \mathrm{hr}$ in Bouin's aqueous fixative and serial 10- $\mu \mathrm{m}$ transverse sections were cut and stained with Weigert's haematoxylin and eosin. The slides were assigned code numbers and were ranked according to the extent of folding of the uterine wall and according to the sectional area of stromal tissue relative to the area of the lumen. In addition, the maximum and minimum heights of the epithelial cells lining the lumen were measured in twelve randomly selected sections from each uterus. From these measurements, the mean epithelial height was obtained.

To induce premature uterine development, $0.3 \mu \mathrm{g}$ stilboestrol in $0.05 \mathrm{ml}$ arachis oil was injected subcutaneously either (i) at 3 and 4 days, or (ii) at 4 and 5 days after birth. In each case, five mice received stilboestrol and five control litter mates received oil only. The uteri were removed at 6 days and were prepared for examination as described above.

During normal development, both the cross-sectional area of the uterus and 

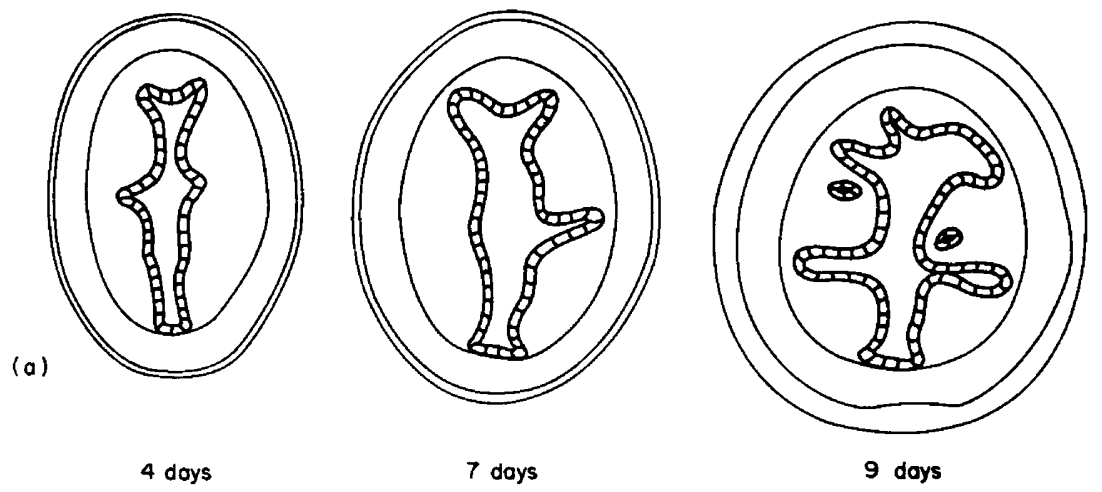

9 days
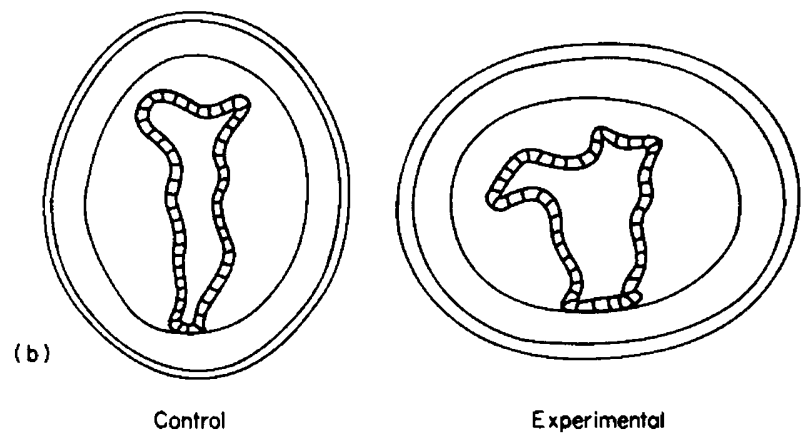

Text-FIG. 1. Transverse sections of mouse uterus (a) during normal development; (b) at 6 days following injection with arachis oil alone (control) and with stilboestrol (experimental).

the amplitude and frequency of folding of the lumen wall increased with age, the most rapid change occurring between 7 and 9 days after birth (Text-fig. 1). With increasing age, the size of the lumen increased slightly relative to the area of the stromal tissue. The mean epithelial cell height decreased gradually from $202 \pm 7 \mu \mathrm{m}$ at 4 days to $156 \pm 5 \mu \mathrm{m}$ at 8 days, and then remained constant till 11 days after birth.

Stilboestrol-treated uteri were always classed as more developed than control uteri although the lumen wall usually showed only small and infrequent folds (Text-fig. 1). The mean epithelial height was significantly increased by stilboestrol (Exp. (i) $240 \pm 4 \mu \mathrm{m}$ compared to $183 \pm 3 \mu \mathrm{m}$; Exp. (ii) $243 \pm 5 \mu \mathrm{m}$ compared to $175 \pm 5 \mu \mathrm{m} ; P<0.001$ in both experiments).

The rapid uterine development occurring between 7 and 9 days after birth suggests that increased concentrations of oestrogen appear in the circulation at this time and inhibit the release of $\mathrm{LH}$, though not of FSH. The decrease in epithelial cell height up to 8 days suggests that protein synthesis may have initially failed to keep pace with cell division as the uterine wall folded and the area of epithelium increased. From 8 days onwards, however, although the number of folds and the luminal area continued to increase, the cell height did not decline further, the endogenous steroid probably promoting both cell division and sufficient protein synthesis. The increased epithelial cell height 
following stilboestrol treatment may reflect both the stimulation of protein synthesis and the small extent of folding. In these uteri, the increased lumen size compared to the area of stromal tissue and the rarity of folds suggest that stromal growth was slow relative to epithelial growth. Thus, the epithelial cells may have been less extended than in normal development.

This work was supported by a grant from the Ford Foundation.

\section{REFERENCES}

DullaArt, J., KeNT, J. \& Ryle, M. (1975) Serum gonadotrophin concentrations in infantile female mice. J. Reprod. Fert. 43, 189-192.

Hadjoloff, A. I., Bourneva, V. \& Motta, P. (1973) Histochemical demonstration of $\Delta^{5}-3 \beta$-OHD activity in the granulosa cells of ovarian follicles of immature and mature mice. Z. Zellforsch. mikrosk. Anat. 136, 215-228.

KENT, J. (1972) Changes in the ovarian follicle population of mice aged 16 to 20 days. F. Reprod. Fert. 31, 323-326.

KENT, J. \& RYLE, M. (1975) Histochemical studies on three gonadotrophin-responsive enzymes in the infantile mouse ovary. F. Reprod. Fert. 42, 519-536. 